\title{
KEBERADAAN HAKIM KOMISARIS DAN TRANSPARANSI DALAM PROSES PENYIDIKAN \\ (The Existence of Judge Commissioner and The Transparency of The Process of Investigation)
}

\author{
Muhaimin \\ Badan Penelitian dan Pengembangan Hukum dan HAMKementerian Hukum dan HAM RI \\ Jalan H.R Rasuna Said Kav. 4-5 Kuningan Jakarta Selatan 12920 \\ Email :eminaltair@gmail.com
}

Tulisan diterima 9-5-2016, Revisi 9-6-2016, Disetujui diterbitkan 21-6-2016

\begin{abstract}
Criminal Procedure Code in the document asserted that the defendant-formation-convict defendant as a "Seeker of Justice", then the suspect-defendant-convict get the attention and protection of the law by setting the portion of his or her rights are quite large. Criminal Procedure Code can be considered as an oriented arrangement of substance abusers. Over \pm 30 years KUHAP rights owned by the perpetrator, especially during the last 10 years, little by little reduced by the law governing criminal procedure in the legislation spread outside the Penal Code. The arrangement does not mean deprivation of the rights of the suspect-defendant-convict who had been there before, but the reduction of quality in the implementation or fulfillment of their legal rights in such a way that essentially contrary to the philosophy underlying the establishment of legal norms in the Code of Criminal Procedure or the laws in the context of political conflict granting legal protection to suspects, accused-convict. Therefore, there should be firmness in the draft Law on Criminal Procedure that the formation of the new Code of Criminal Procedure did not reduce or remove the least the rights of suspects, defendants, and convicts who have been published in the Code of Criminal Procedure, on the contrary the Draft Law on the Law of Criminal Procedure in fact strengthen it with more concrete legal instruments and easy to apply.
\end{abstract}

Keywords: Judge Commisioner, Supervision, Inspection

\begin{abstract}
ABSTRAK
Dokumen KUHAP menegaskan bahwa terdakwa-narapidana sebagai "Pencari Keadilan", maka tersangkaterdakwa-narapidana mendapatkan porsi perhatian dan perlindungan hukum dengan menetapkan bagian hak yang cukup besar. KUHAP dapat dianggap sebagai suatu pengaturan untuk pelaku substansi. Selama \pm 30 tahun hak KUHAP yang dimiliki oleh pelaku, terutama selama 10 tahun terakhir, sedikit demi sedikit dikurangi dengan hukum yang mengatur acara pidana dalam perundang-undangan yang tersebar di luar KUHP. Pengaturan ini tidaklah berarti perampasan hak-hak tersangka-terdakwa-narapidana yang sudah ada sebelumnya, tapi pengurangan kualitas dalam penerapan atau pemenuhan hak-hak hukum mereka sedemikian rupa yang pada dasarnya bertentangan dengan filosofi yang mendasari pembentukan norma hukum dalam KUHAP atau hukum dalam konteks konflik politik pemberian perlindungan hukum untuk tersangka-terdakwanarapidana. Oleh karena itu, harus ada ketegasan dalam draft UU Acara Pidana bahwa pembentukan Kode baru Acara Pidana tidak mengurangi atau menghapus setidaknya hak-hak tersangka, terdakwa, dan narapidana yang telah diterbitkan dalam KUHAP, Sebaliknya, RUU tentang Hukum Acara Pidana, pada kenyataannya, memperkuatnya dengan instrumen hukum yang lebih konkret dan mudah diterapkan.
\end{abstract}

Kata Kunci: Hakim Komisaris, Pengawasan, Pemeriksaan 


\section{PENDAHULUAN}

Undang-Undang Nomor 8 tahun 1981 tentang Kitab Undang-Undang Hukum Acara Pidana (KUHAP) telah berusia lebih dari seperempat abad (+ 35 tahun), sering disebut sebagai hasil karya "agung" bangsa Indonesia dibuat para pakar hukum acara pidana Indonesia yang disertai dengan integritas dan semangat untuk mewujudkan penyelenggaraan pemerintahan yang melindungi kepentingan warga negara sesuai dengan Pembukaan UUD 1945.

Ketentuan hukum acara pidana (Pasal 50 Pasal 56 KUHAP) dimaksudkan untuk melindungi tersangka dan terdakwa dari tindakan yang sewenang-wenang aparat penegak hukum dan pengadilan. Pada sisi lain, hukum acara memberi kewenangan kepada aparat penegak hukum untuk melakukan tindakan yang dapat mengurangi hak asasi warganya, akan tetapi sering terjadi penggunaan kewenangan yang tidak benar oleh aparat penegak hukum. (Agus Raharjo, Angkasa dan Hibnu Nugroho, 2012:2) Praktik peradilan pidana yang mengedepankan kekerasan sehingga hak-hak asasi warga negara terampas merupakan bentuk kegagalan negara dalam mewujudkan negara hukum.(ibid)

Polisi merupakan garda terdepan dalam Sistem Peradilan Pidana (SPP), yang diberi hak dan wewenang untuk melakukan penyelidikan, penyidikan, penangkapan dan penahanan terhadap seseorang yang dicurigai atau disangka melakukan tindak pidana. Tidaklah berlebihan jika polisi dikatakan sebagai hukum pidana yang hidup, (ibid,:3) yang menterjemahkan dan menafsirkan law in the book menjadi law in action.

Sistem Peradilan Pidana memiliki sifat kriminogen,(ibid) dan dalam tubuh kepolisian, sifat kriminogen itu muncul dalam tahap penyidikan. Perilaku polisi yang sering mendapat kritikan adalah berkaitan dengan penggunaan kekerasan dalam pelaksanaan tugas. Indriyanto Seno Adji mengemukakan bahwa perilaku sedemikian telah membudaya, terutama dalam penyidikan untuk mendapatkan pengakuan terdakwa. (Indriyanto Seno Adji, 1998:4)

Hukum Acara Pidana dibuat untuk menggantikan Herzein Inlands Reglement (HIR), ciptaan pemerintah kolonial Belanda. Dalam perjalanannya KUHAP telah banyak perkembang- an khusus dalam bidang ilmu pengetahuan dan teknologi yang harus segera diantisipasi oleh bangsa Indonesia agar hukum acara pidana tidak ketinggalan dengan perkembangan di era globalisasi.

Sejalan dengan hal tersebut perkembangan hubungan kemasyarakatan di dunia internasional juga sangat pesat, ditandai dengan berbagai konvensi internasional yang berkaitan dengan berbagai bidang kehidupan yang perlu diikuti oleh Indonesia sebagai bagian dari masyarakat internasional. Konvensi-konvensi internasonal yang berkaitan dengan keberadaan KUHAP telah banyak yang diratifikasi oleh Indonesia. Konvensi Internasional tentang International Crimininal Court, United Nations Actions Against Corruption, International Convention Against, Torture dan Internanational Covenant on Civil and Political Rights (ICCPR), merupakan konvensi-konvensi yang berkaitan langsung dengan hukum acara pidana yang lahir sesudah adanya KUHAP tahun 1981.(Andi Hamzah, 2009:4)

Sebagai Negara yang telah meratifikasi berbagai konvensi tersebut terhadap kewajiban untuk mengikuti ketentuan yang diatur dalam konvensi. Sebagai contoh dapat dikemukakan dalam kovenan tentang hak-hak sipil dan politik $(I C C P R)$ terdapat ketentuan yang berkaitan dengan hukum acara pidana, misalnya tentang hak-hak tersangka dan ketentuan penahanan yang diperketat. Berhubungan dengan hal tersebut ada Negara-negara yang membuat KUHAP baru untuk mengikuti konvensi Internasional, antara lain Italia, Rusia, Lithuania dan lain sebagainya.

Ada pula Negara yang mengubah KUHAPnya, agar selaras dengan ketentuan konvensi tersebut misalnya Perancis. Pada tahun 2000, Perancis menyisipkan ketentuan baru dalam hukum acara pidana mengenai hak asasi manusia, seperti hukum acara pidana haruslah fair dan adversarial, dan menyeimbangkan hak-hak para pihak, orang dalam situasi yang sama dan dituntut atas delik yang sama haruslah detail berdasarkan aturan yang sama.

Sedangkan Kitab Undang-undang Hukum Acara Pidana di Jepang diperkenalkan sistem baru, yaitu sistem campuran, yang menggabungkan antara hakim dan juri. Dengan sistem tersebut dicampur antara hakim karir dengan orang awam (laymen) (Ubbe, 2009:71) 


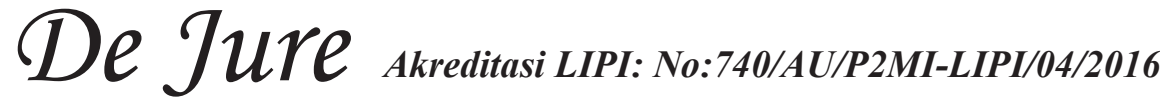

Dari uraian di atas dapat ditarik suatu benang merah bahwa KUHAP di Indonesia yang sudah berusia lebih dari seperempat abad harus pula diperbaharui agar sesuai perkembangan ilmu pengetahuan dan teknologi serta perkembangan masyarakat dan perkembangan ketentuanketentuan internasional yang berkaitan dengan hukum acara pidana. Dengan telah diratifikasi beberapa konvensi internasional khusus ICCPR yang terkait langsung dengan hukum acara pidana misalnya tentang penahanan yang dilakukan oleh penyidik harus sesingkat mungkin dan sesegera mungkin adalah dua kali dua puluh empat jam. Di Eropa umumnya diartikan paling lama 5 (lima) hari atau 1 (satu) hari penangkapan dan 4 (empat) hari penahanan. Sedangkan dalam KUHAP masa penahanan 20 hari dinilai terlalu lama dan bertentangan dengan International Convention Against Torture dan International Covenant on Civil and Political Rights (ICCPR), Against Torture dan International Covenant on Civil and Political Rights (ICCPR), yang telah diratifikasi oleh Indonesia.

Selain kedua konvensi tersebut di atas masih terdapat beberapa konvensi seperti konvensi anti penyiksaan serta konvensi hak-hak asasi manusia yang belum diratifikasi oleh pemerintah Indonesia, teori Herbert L. Packer tentang crime contol model dan due process model, dan teori integrated criminal justice system.

Berbagai substansi dalam KUHAP yang perlu diantisipasi antara lain penjelasan mengenai "asas legalitas" dalam KUHAP dengan KUHP, karena perbedaan antara asas legalitas dalam hukum pidana lembaga peradilan karena sifatnya pasif dengan sistem lain yang sifatnya lebih proaktif sangat penting untuk ditindaklanjuti.

Agar dapat mengatasi hal ini, maka untuk dapat mengantisipasi adalah melakukan perubahan Undang-Undang Nomor 8 Tahun 1981 dengan menambah peraturan mengenai Hakim Komisaris.

Dengan dibentuknya profesi dan fungsi hakim komisaris maka dapat dicapai tujuan hukum acara pidana due process of law atau behoorlijk process recht. Hakim komisaris dimulai di Perancis dengan Code d'instruction ditetapkan dan dengan undang-undang Strafvordering yang berlaku sejak tahun 1926 tetap ada hakim komisaris atau rechter commissaris, begitu pula di Italia.
Tujuan hukum acara pidana ialah mencapai obyektif truth dan melindungi hak asasi terdakwa dan jangan sampai orang tidak bersalah dijatuhi pidana, diadakan pengecekan terhadap terdakwa, saksi dan bukti lain hakim komisaris diberi wewenang untuk memberi perintah penahanan, penggeledahan dan upaya paksa.

Di Perancis sejak tahun 2001 wewenang tersebut diserahkan kepada hakim yang berwenang menahan dan memerdekakan orang dari tahanan (judge des liberte et de la detention) yang terdiri dari tiga orang yang diketahui oleh wakil ketua pengadilan. Jadi penahan semakin diperketat di Perancis. (Hamzah, 2009:7)

Sekarang ini Nederland asas oportunitas telah lebih jauh diterapkan yang transaksi dapat dilakukan terhadap perkara ringan yang ancaman pidananya enam tahun ke bawah dan jaksa dapat menekan denda administratif. Bandingkan dengan Swedia, Norwegia dan Rusia pada uraian di muka. Perancis ingin mengurangi peran hakim komisaris sedangkan Nederland ingin memperkuat.

Mula-mula di Perancis judge d'instruction memiliki wewenang seperti jaksa Belanda yaitu memimpin penyidikan akan tetapi karena terjadi skandal seks terhadap anak yang menimpa hakim komisaris di sana, maka wewenangnya itu mulai dikurangi. Perancis membagi acara pidana atas dua bagian yaitu pemeriksaan penyidikan, yang dilakukan oleh jaksa dan polisi dan pemeriksaan sidang. Penahanan yang dilakukan oleh polisi harus dapat menahan delapan hari yang semuanya dipertanggung jawabkan oleh jaksa.

Jaksa dapat memilih membiarkan polisi terus melakukan penyidikan atau melakukan pemeriksaan pre-trial. Pemeriksaan pendahuluan oleh hakim disebut informationjudiciaire. Dalam hal pemeriksaan pendahuluan ditemukan delik lain, maka hakim komisaris harus memberitahu jaksa agar memperluas pemeriksaan. Hakim komisaris yang memimpin pemeriksaan dapat memberi perintah penyadapan dan penahanan.

Kodifikasi Hukum Acara Pidana Italia yang mulai berlaku 24 Oktober 1989 membuang sistem Perancis (yang diikuti Nederland dan Indonesia). Dalam sistem Italia yang baru ini jaksa dikeluarkan dari kekuasaan kehakiman (magistrate) dan berlaku system accusatoir murni atau adversary system. Mula-mula pertentangan pada tahun 1990 sehingga diperkenalkan lagi beberapa asas "inquisitori". Kemudian system adversary 
diperkenalkan lagi sama seperti diatur di dalam KUHAP 1989.

\section{Sistem KUHAP 1989 ini berdasarkan :}

1. Pelepasan fungsi dari peradilan, dan

2. Pemisahan pre trial dan trial (praperadilan dan peradilan).

Akibat lebih jauh ialah penghapusan gludice instructorre yang dulu ditiru dari Perancis dan diganti dengan lembaga baru yang tidak melakukan penyidikan yaitu Giudice per le indagini preliminary. Lembaga baru ini mirip dengan system hakim komisaris dalam R-KUHAP.

Penghapusan Pretore magistrate yang yurisdiksinya delik ringan yang ancaman pidananya maksimum empat tahun tanpa hadir jaksa. Pemisahan yang tajam antara penyidikan penuntutan dan peradilan untuk menjaga hakim tidak memihak (impartial) sehingga dengan inisiatif hakim dapat dicari bukti sendiri.

KUHAP Italia 1989 bermaksud agar sidang dibuka dengan segar, yang jelas memisahkan secara tajam investigation phase dan adjudication phase. Hasil penyidikan polisi dan jaksa dibuat rangkap dua:

1) Suatu berkas (file) yang berisi pemeriksaan penggeledahan dan penyitaan barang dan penyadapan diserahkan kepada hakim,

2) Berkas lain yang berisi seluruh hasil penyidikan seperti keterangan saksi dan tersangka tetap berada di tangan para pihak (jaksa dan penasehat hukum) yang dapat diadu dengan keterangan saksi atau terdakwa yang tidak konsisten di sidang pengadilan.

Oleh karena hakim komisaris (giudice instructorre) dihapus, maka penyidikan oleh jaksa dibawah kontrol oleh hakim, yang sama sekali baru yang menghilangkan kewenangan untuk mengumpulkan bukti seperti magistrate Amerika atau Ermittlungsrichter di Jerman.

Fungsi pre trial judges yang baru dibatasi hanya dalam mengeluarkan surat perintah penahanan, persetujuan penyadapan, mengawasi penataan atas waktu yang boleh untuk penyidikan dan pengumpulan bukti awal jika dikhawatirkan akan dihilangkan. Hal ini mirip sekali dengan fungsi hakim komisaris versi R-KUHAP yang istilahnya diambil dari Nederland Rechter Commissaris tetapi tugasnya tidak sama. Tugas guidice per le inddagibi preliminary di Italia mirip dengan tugas juge des liberte et de la detention di Perancis. Jika hasil penyidikan diputuskan akan diteruskan dengan penuntutan hakim pre trial dapat mengeluarkan putusan dalam pemeriksaan pendahuluan (preliminary examination) untuk menyaring penuntutan yang tergesa-gesa seperti di common law.

Dengan undang-undang tahun 2003 diperkenalkan juga plea bargaining dengan persetujuan penuntut umum, terdakwa dapat memohon untuk dipidana sampai lima tahun penjara. Bandingkan dengan sistem Rusia yang telah disebut di muka. Pembuat undang-undang Italia meenolak diskresi penuntut(asas oportunitas) karena pasal 112 UUD Italia menganut asas legalitas yang jaksa harus menuntut jika cukup bukti.

Dalam penerapan sistem baru ini tidak mulus, karena KUHAP 1989 membatasi kebebasan penuntut umum dengan menempatkan di bawah control hakim dalam pemeriksaan pendahuluan yang rumit (crucial). Akan tetapi dalam praktek jaksa sangat bebas dalam melakukan investigasi.

(Hamzah, 2007:217)

Tidak kurang pentingnya di samping membicarakan lembaga baru hakim komisaris juga masalah tentang pembuktian. Ada anjuran dari pakar Amerika tersebut, bahwa sebaliknya barang bukti yang mereka sebut real evidence atau physical evidence dimasukan sebagai alat bukti seperti KUHAP banyak Negara termasuk Amerika. Namun karena Indonesia menganut system pembuktian negatifwettelijk, artinya harus ada dua alat bukti menurut undang-undang ditambah dengan keyakinan hakim baru terdakwa dapat dijatuhi pidana, makabarang bukti seperti pistol yang dipakai menembak, pisau yang dipakai menusuk, fungsinya ialah untuk memperkuat keyakinan hakim.

Bahkan di Jerman dikenal saksi yang tidak melihat tidak mendengar dan tidak mengalami terjadinya delik, namun hakim dapat memanggil seseorang sebagai saksi, yang mengerti benar karakter terdakwa atau korban. Sebenarnya ini cocok dengan system pembuktian negatif wettelijk yang dianut di Indonesia (sama dengan di Nederland) yang baru ada dua alat bukti ditambah dengan keyakinan hakim untuk menjatuhkan pidana. 


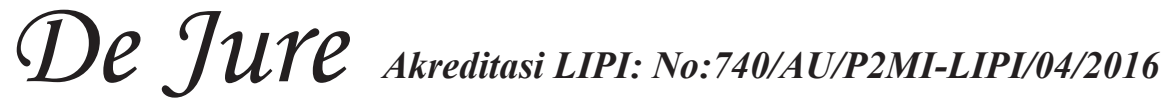

Hal baru dalam rancangan ialah barang bukti yang lazim disebut di Negara lain real evidence atau materiel evidences yaitu bukti yang sungguhsungguh. Disebut surat-surat (jamak) maksudnya ialah jika ada seratus surat, dihitung sama dengan satu alat bukti. Sebaliknya disebut seorang ahli atau seorang saksi, maksudnya jika ada dua saksi maka memenuhi bukti minimum dua alat bukti. Ini sama dengan KUHAP Belanda yang menyebut geschriftelijke bescheiden (surat-surat) dan verklaringen van een getuige (keterangan seorang saksi). Bukti elektronik misalnya e-mail, SMS, foto, film, fotocopy, faximilie, dan seterusnya. (Hamzah, 2007:7)

Sengaja keterangan saksi ditempatkan bukan pada urutan satu (sama dengan KUHAP Belanda) agar jangan dikira jika tidak ada sanksi tidak ada alat bukti. Keterangan terdakwa berbeda dengan pengakuan terdakwa. Alat bukti petunjuk yang berasal dari KUHAP Belanda tahun 1838 yang sudah lama diganti dengan eigen waarneming va de rechter (pengamatan hakim sendiri) berupa kesimpulan yang ditarik dari alat bukti lain berdasarkan hasil pemeriksaan di sidang pengadilan. Di Amerika Serikat disebut judicialnotice. Tidak ada KUHAP di dunia yang menyebut petunjuk (Belanda: aanwijzing, Inggris : indication) sebagai alat bukti kecuali kodifikasi Belanda tahun (1838); HIR dan KUHAP (1981).

Dalam requisitoir-nya penuntut umum dapat menguraikan dan menjelaskan hal-hal yang terjadi di sidang pengadilan dan memberi kesimpulan dari semua alat bukti yang telah dikemukakan, untuk memancing opini hakim yang menjurus kepada adanya bukti berupa pengamatan hakim sendiri.

Alatbukti keterangan saksi sebenarnya dalam rumusan Belanda disebut verklaringen van een getuige (keterangan seorang saksi) yang berartijika ada dua saksi maka sudah cukup dan merupakan dua alat bukti (bukti minimum). Sebaliknya untuk surat dipakai istilah jamak (geschriffen) yang berarti walaupun ada sepuluh surat dihitung sebagai satu alat bukti saja. Kesulitan di Indonesia dalam menyusun rumusan undang-undang pidana ialah karena bahasa Indonesia tidak mengenal singular dan plural. Misalnya dalam rumusan Pasal 338 KUHP dikatakan merampas nyawa orang lain, padahal bahasa Belanda "een ander" (satu orang lain). Jadi jika 102 orang dibunuh seperti bom Bali, maka 102 kali 340 KUHP. Oleh karena KUHAP menyebut alat bukti keterangan saksi, maka ada yang berpendapat jika dua orang saksi merupakan satu alat bukti saja, harus dicari alat bukti lain, padahal sudah cukup.

Perlu pula ditinjau tentang upaya hukum KUHAP 1981 tidak membolehkan banding terhadap putusan lepas dari segala tuntutan hukum, sehingga dalam praktek ditafsirkan oleh jaksa dan hakim boleh langsung dikasasi. Sebenarnya prinsip upaya hukum ialah tidak ada kasasi tanpa pengadilan banding terlebih dahulu. Hal itu dimaksud agar jangan terlalu banyak perkara masuk ke Mahkamah Agung.

Upaya hukum luar biasa berupa peninjauan kembali yang harusnya bersifat luar biasa karena seharusnya jarang sekali tiga tingkat pengadilan yang terdiri dari sembilan orang hakim (3 di pengadilan negeri, 3 di pengadilan tinggi dan 3 di Mahkamah Agung), semuanya keliru, sehingga tidak melihat putusan yang saling bertentangan, salah menerapkan hukum dan kurang teliti sehingga kemudian timbul novum. Misalnya terdakwa dipidana karena saksi yang memberatkan bersumpah palsu. Ada KUHAP yang tidak mencantumkan upaya hukum peninjauan kembali misalnya KUHAP Thailand. Yang ada dalam KUHAP Thailand ialah pengampunan (pardon) dan pengurangan pidana oleh raja.

Putusan saling bertentangan, misalnya dua orang yang didakwa melakukan delik ikut serta (medeplegen) yang perkaranya dipisah, yang satu dijatuhi pidana karena terbukti melakukan delik ikut serta dengan yang lain, sedangkan yang lain itu diputus bebas atau lepas dari segala tuntutan hukum. Contoh S. Tjandra diputuskan lepas dari segala tuntutan hukum karena perbuatannya itu (cessie) adalah perbuatan perdata bukan pidana. Kemudian Pande Lubis dijatuhi pidana karena terbukti melakukan perbuatan korupsi (medeplegen) dengan Djoko S. Tjandra. (Kaligis, 2006:338)

Dalam rancangan disebut juga Jaksa Agung dapat memohon peninjauan kembali, bukan untuk orang yang diputus bebas, tetapi mereka yang dijatuhi pidana, kemudian ternyata ada novum atau putusan saling bertentangan. Hal ini sama dengan ketentuan dalam KUHAP $(S v)$ Nederland. Di sini jaksa agung mewakili masyarakat, misalnya terpidana itu telah meninggal dunia dan tidak ada ahli warisnya yang mengajukan peninjauan 
kembali. Di Belgia menteri kehakiman yang dapat memohonkan peninjauan kembali.

Salah satu hal yang paling sering disalahgunakan ialah saksi mahkota. Ada yang mengartikan saksi mahkota ialah jika para terdakwa bergantian menjadi saksi atau kawan berbuatnya. Justru hal itu dilarang karena berarti selfincrimination. Sebagai saksi dia disumpah, jadi jika dia berdusta dia bersumpah palsu, padahal dia juga terdakwa dalam kasus itu yang jika dia berdusta tidak diancam dengan pidana. Saksi mahkota hanya ada dalam buku teks dan yurisprudensi, tidak tercantum di dalam undangundang. Saksi mahkota ialah salah seorang terdakwa/tersangka yang paling ringan perannya dalam delik terorganisasikan yang bersedia mengungkap delik itu, dan untuk jasanya, dia di keluarkan dari daftar tersangka/terdakwa dan dijadikan saksi. Jika tidak ada peserta (tersangka/ terdakwa) yang ringan perannya dan tidak dapat dimaafkan begitu saja, tetap diambil yang paling ringan perannya dan dijadikan saksi kemudian menjadi tersangka/terdakwa dengan janji oleh penuntut umum akan menuntut pidana yang lebih ringan dari kawan berbuatnya yang lain. Demikian ketentuan undang-undang Italia tentang "saksi mahkota". Jadi ketentuan tentang saksi mahkota yang dituangkan di dalam pasal 198 Rancangan sesuai dengan asas oportunitas juga yang dianut di Indonesia. Tentu hal ini harus disampaikan oleh penuntut umum kepada hakim. Penuntut umumlah yang menentukan terdakwa dijadikan saksi mahkota.

Adapun dasar pemikiran amandemen Undang-Undang Nomor 8 Tahun 1981 dengan menambah keberadaan Hakim Komisaris sebagai upaya perlindungan terhadap HAM dari terdakwa, baik dalam proses penyidikan dan penuntutan, didasarkan pada beberapa pemikiran sebagai berikut :

\section{Alasan Filosofis}

Landasan filosofis merupakan landasan yang bersifat ideal, yang dapat memotivasi aparat penegak hukum mengejar dan mengarahkan semangat dan dedikasi pengabdian penegakan hukum, berusaha mewujudkan keluhuran makna dan hakekat yang terkandung dalam jiwa landasan filosofis tersebut
2. Alasan Yuridis

UUD 1945 terutama Pasal 20 (tentang legislasi), Pasal 21 (hak DPR mengajukan RUU), Pasal 22 (hak Presiden untuk mengajukan Perpu), Pasal 22A (tata cara pembentukan undang-undang), Pasal 24 (kekuasaan kehakiman), Pasal 24A (wewenang Mahkamah Agung), Pasal 24C (wewenang Mahkamah Konstitusi), Pasal 28A sampai dengan Pasal 28J (hak asasi manusia).

Pasal 27 UUD 1945 berbunyi "Segala warga negara bersamaan kedudukannya di dalam hukum dan pemerintahan dan wajib menjunjung hukum dan pemerintahan itu dengan tidak ada kecualinya". Dengan demikian pemerintah harus membuat ketentuan yang mengatur bahwa kedudukan hukum setiap warga negara sama/sederajat. KUHAP merupakan salah satu ketentuan peraturan perundang-undangan yang mengatur mengenai hal tersebut.

3. Alasan Sosiologis

Masyarakat khususnya para pencari keadilan sering mengeluhkan berbagai hal yang berkaitan dengan proses acara pidana yang cenderung lama dan berbelit-belit, sehingga sangat merugikan para pencari keadilan, baik ditinjau dari sisi waktu, tenaga maupun biaya.

4. Alasan Efisiensi dan Efektifitas

Hukum acara akan berkaitan dengan hak konstitusional warganegara dan juga sumber daya yang dimiliki Negara, apabila tahap-tahap yang ditentukan oleh hukum acara pidana dapat efisisen dan efektif, maka akan menguntungkan bukan hanya waraga Negara yang berurusan dengan masalah pidana tetapi juga Negara.

5. Dasar Ekonomis

Seluruh pasal didalam KUHAP mengacu pada system peradilan cepat (speedy trial, contante justitie) sederhana dan biaya ringan. Perkenalan system peradilan cepat dituangkan antara lain dalam pengajuan perkara melalui jalur khusus penyelesaian diluar acara (afdoening buiten process) dalam upaya hukum semua perkara harus lewat Pengadilan Tinggi baru dapat diajukan 


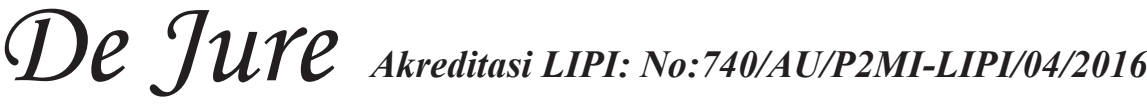

permohonan kasasi ke Mahkamah Agung untuk mengurangi beban mahkamah agung.

Pada pendahuluan telah dikemukakan akan dibentuknya hakim komisaris yang akan mengganti peran praperadilan yang tidak efektif. Hakim komisaris ini tidak persis sama dengan yang ada di Eropa. Seperti Rechter Commissaris di Netherland, juge d'instruction di Perancis, Giudice instructore di Italia. Oleh karena itu di Eropa dan Amerika dibentuk investigating magistrate. Maksudnya ialah mengimbangi jaksa yang sangat dominant sebagai master of procedure atau dominus litis. Maksudnya ialah menyaring perkara-perkara besar dan menarik perhatian masyarakat yang akan diajukan oleh jaksa ke pengadilan.

Dengan adanya lembaga penyaring di samping hakim (trial judge) maka dapat dihindari penuntutan yang sewenangwenang yaitu karena alasan pribadi atau balas dendam, atau yang khusus Indonesia penuntut umum ingin dikatakan berhasil dengan system target. Penuntutan menurut cara itu disebut malice prosecution atau penyalahgunaan penuntutan (abuse of prosecution) yang tidak dapat dibenarkan oleh hakim.

Bahwa pada jaman Hindia Belanda ada Hakim Komisaris yang dinamakan "landraad" yang mempunyai tugas mengawali pemeriksaan perkara-perkara yang terhambat maupun perkara-perkara gabungan Hukum Belanda dan hukum Hindia Belanda. Tapi landraad menjelang Perang Dunia ke 2 menjadi tidak berfungsi hal ini dikarenakan adanya intervensi menyangkut keadaan darurat. Infasi/penyerbuan Jepang pada perang dunia ke-2, jadi landraad muncul kemudian tenggelam; karena pemerintah Hindia Belanda dipindahkan ke Australia. Setelah Jepang menyerah ada gagasan "lit landraad " diganti dengan Hakim Komisaris, sesuai / sinkron dengan induk negara Belanda di Eropa. Jadi dengan demikian timbul tenggelamnya ide lembaga Hakim Komisaris itu sejak lama, namun tidak terlaksana. Kegagalan tertunda-tundanya menjadi perhatian untuk bahan penulisan ini, jadi dengan demikian fakta itu menjadi bahan masalah Mengapa peradilan tidak sepenuhnya melakukan pengawasan dalam proses pemeriksaan terhadap tersangka, terdakwa, dan terpidana? dan Bagaimana Keberadaan Hakim Komisaris dan Perlindungan terhadap Hak Asasi Manusia dalam Proses Pemeriksaan Terhadap Tersangka dan Terdakwa?

\section{Metode Penelitian}

Adapun metode penelitian yang digunakan, yaitu: metode penelitian hukum normatif (studi kepustakaan), yaitu: suatu penelitian yang dilakukan atau didasarkan pada ketentuanketentuan yang seharusnya atau teori yang ditentukan dari bahan-bahan yang terdiri dari:

1. Bahan Hukum Primer, yaitu bahan-bahan penelitian yang berupa ketentuan-ketentuan yang utama. Bahan penelitian ini, bahan primer yang digunakan oleh penulis antara lain: Kitab Undang-Undang Hukum Pidana; Undang-Undang Nomor 1 Tahun 1946 tentang Peraturan Hukum Pidana, UndangUndang Nomor 8 Tahun 1981 tentang Hukum Acara Pidana, Undang-Undang Nomor 2 Tahun 2002 tentang Kepolisian Republik Indonesia,Undang-Undang Nomor 16 Tahun 2004 tentang Kejaksaan Republik Indonesia, Undang-Undang Nomor 3 Tahun 2009 tentang Mahkamah Agung, UndangUndang Nomor 48 Tahun 2009 tentang Kekuasaan Kehakiman

2. Bahan Hukum Sekunder, yaitu bahan hukum yang erat kaitannya dengan bahan hukum primer dan dapat membantu menganalisis bahan hukum primer. Bahan-bahan hukum sekunder yang penulis gunakan terdiri dari buku-buku, dan bahan-bahan hukum lainnya yang berkaitan dengan penulisan ini

3. Bahan Hukum Tertier, yaitu bahan-bahan yang memberi petunjuk, penjelasan dan pemahaman terhadap bahan hukum primer dan sekunder, seperti: Black's Law Dictionary, Kamus Besar Bahasa Indonesia, dan Kamus Lengkap Inggris - Indonesia, dan Indonesia Inggris (dengan Ejaan yang Disempurnakan (Soekanto, 1986: 52-53) 


\section{PEMBAHASAN}

\section{A. Peradilan Tidak Sepenuhnya karena tidak ada Pengawasan}

Padamasalalusebelumabad18banyaknegara yang menyelenggarakan pemerintahan absolute dalam arti penguasa mendominasi kedaulatan bagi kepentingan kekuasaan absolute, berlanjut pada penetapan hukum dan penerapan hukum pun sejajar dengan pengertian penguasa absolute sehingga Pengadilan juga menganut absolutism. Pengadilan sebagai pemegang kekuasaan hukum menyelenggarakan peradilan tidak berbeda jauh dengan penguasa absolute. Kenyataan di sebagian besar negara dalam praktek Pengadilan menjalangkan kekuasaan penguasa negara, walaupun sudah menggunakan dalil "Freedom of justice" yang bernafaskan faham Rousseau dan Montesqiuw. Logika hukum tersumbat, keadilan tampak memihak dan banyak Putusan Pengadilan mengorbankan pihak rakyat dan menghindar jika menghadapi alat-alat Penguasa yang melanggar hukum.

Dalil yang konvensional tentang penegakan hukum di Pengadilan sudah harus menjadi pengetahuan umum bukan sekedar petugas penegak hukum tetapi sudah menjadi konsep masyarakat bahwa penegakan hukum terutama di Pengadilan harus berdasarkan (1) kepastian hukum (rechtssicherkeit), keadilan (gerechtigkeit) dan kemanfaatan (zweckmassigkeit), walaupun secara proporsional sulit untuk diseimbangkan antara ketiga unsur tersebut, namun faktor kemampuan "knowledge, skill, norm-value" ataupun faktor bobot perkaranya harus menjadi tantangan pembaharuan hukum dan peradilan.

Dalil konvensional ini semakin rapuh jika bobot keputusan pengadilan semakin rendah, dan sudah selayaknya perlu direnovasi menjadi Pengadilan masa kini yang solid dan mengikuti perkembangan zaman serta kemajuan masyarakat. Walaupun konsep demokrasi hamper sepenuhnya bersumber dari benua Eropa dan Amerika, karena di benua Asia dan Australia yang menjadi lahan penjajahan maka kehidpan demokrasi tersumbat oleh sistem pemerintahan model penjajah. Namun di Eropa dan Amerika itu ternyata terdapat kasus ketidakadilan dan kesesatan hukum di Pengadilan menjadi terkenal di dunia. Kasus ketidakadilan dan kesesatan hukum yang menjadi praktek buruk di Pengadilan, dan menjadi catatan kelemahan hukum di dunia adalah kasus Jean Calas, kasus Captain Dreyfuse, kasus Van Der Lubbe, kasus Miranda, dan lain-lainnya.

Gerakan Internasional yang memperbaiki dan kehandalan para penegak hukum di peradilan masa kini dan masa depan mulai dicetuskan tahun 1870 di London dengan membentuk "International Committee Penal and Penitentiary" (ICPP) dan setelah 80 tahun berubah menjadi komisi internasional "The Prevention of Crime, and the Treatment of Offender" (PCTO) kurang lebih tahun 1956 dibawah naungan Perserikatan Bangsa-Bangsa. Kemudian disusul berbagai sub-organisasi lainnya, dan yang paling ekstrim adalah perkumpulan internasional "Gerakan Abolusionis Terhadap Sistem Peradilan Pidana" untuk membuka mata peradilan yang lemah.

Perkembangan peraturan hukum acara pidana di Indonesia tampak sudah cukup luas meliputi bidang hukum acara pidana umum dan hukum acara pidana khusus. Peraturan hukum acara pidana umum termuat didalam KUHAP dan peraturan perundangan bermuatan struktur, fungsi dan beracara perkara pidana umum. Sedangkan peraturan hukum acara pidana khusus termuat didalam perundang-undangan diluar KUHAPyang bermuatan peraturan eksepsional struktur, fungsi dan beracara perkara pidana khusus sebagaimana tercermin pada pasal 284 (2) KUHAP.

Perkembangan substansi hukum acara pidana umum diharapkan terutama dari KUHAP dalam Undang-Undang Nomor 8 Tahun 1981 tentang Hukum Acara Pidana yang diundangkan pada tanggal 31 Desember 1981. Keberlakuan KUHAP dihandalkan sebagai kodifikasi pembahruan hukum acara pidana akan tetapi kenyataannya segera setelah berlaku terlihat kekurangan yang menjadikan awal kesulitan untuk penerapannya dan ditambah dengan rumusan pasal yang berpeluang untuk terjadinya berbagai interpretasi dari suatu kepentingan hukum.

Di bidang umum permasalahan KUHP harus menyesuaikan dengan konsep hukum acara pidana berdasarkan:

(1) Pencerminan sendi-sendi hukum acara pidana yang bersifat universal, antara lain menyangkut tindakan aparatur negara yang dapat dipertanggugnjawabkan secara hukum apabila melanggar Hak Asasi Manusia. Pertanyaannya adalah apakah dalam 


\section{De Jure Akreditasi LIPI: No:740/AU/P2MLLLIPIOA42016}

prakteknya sudah melaksanakan sendi hukum yang bersifat universal walaupun asas universal tersebut tidak jelas-jelas terumuskan dalam suatu Pasal KUHAP?

(2) Menjamin berlakunya deklarasi maupun konvensi internasional tentang The Universal Declaration of Human Right (tanggal 10 Desember 1948), dan The International Covenant on Civil and Political Right (16 Desember 1966). Pertanyaannya adalah apakah dasar hukum tidak tertulis itu sudah direalisasikan setiap bagian penyelenggaraan hukum acara pidana dalam KUHAP? Mengapa sebagian masyarakat luas menuntut perlakukan berdasarkan Hak Asasi Manusia dan Komnas HAM Indonesia telah berapa kali memberikan sorotan tajam mengenai hal ini?

(3) Pertama kalinya di Indonesia diperkenalkan secararesmitentang TheIntegratedofcriminal system melalui S.K. Menteri Kehakiman 1982 yang adaptasi dari kepustakaan hukum. Apakah memahami sistem peradilan pidana terpadu itu dan melaksanakan secara konsekuen? Mengapa sering terjadi kewenangan dan interpretasi yang bersifat instansi sentries dan fragmatisme, sehingga timbul masalah yang tidak terkoordinasi secara terpadu? Apa sebabnya suatu masalah yang pada kesempatan diskusi panel ini masih muncul permasalahan lama?

(4) Dalam S.K. Menteri Kehakiman 1982 diasumsikan bahwa Hukum Acara Pidana Baru (KUHAP) akan diuji kebenarannya atas sebutan sebagai karya agung, dan pada hakekatnya KUHAP baru merupakan bentuk formal yang disertai oleh sikap formalisme belaka diri segenap anggota masyarakat dan segenap penegak hukum untuk merubah wajah hukum masyarakat Indonesia menjadi lebih berperikemanusiaan!

Eksistensi dan penyelenggaraan the integrated criminal justice system diartikan proses management (perilaku yang mempunyai tujuan tertentu) dari raw-input, instrumental input, environment input sebagai bagian komponen sistem proses untuk saling berhubungan dalam interrelasi dan interaksi mewujudkan suatu hasil berupa output dari tujuan diadakannya peradilan pidana guna mencapai cita-cita social civilization dan unwelfare.

Namun banyak pengamat sosial yang memperingatkan bahwa apa yang dinamakan the integrated criminal juctice system masih dianggap mengidap (laten) masalah "distributing issue on social problem" dari karakter peradilan pidana, dan kurangnya perhatian terhadap integrasi yang mencakup koordinasi (vide uraian 2 (3) tersebut diatas) karena fragmentaris dan instansi sentris.

Konsepsi integrasi-integrasi mengandung pengertian the achievement of unification through shared norm and value yang harus tampak dalam penyelenggaraan dan penyelenggara peradilan pidana. Sehubungan dengan karakter peradilan pidana dan upaya sistem peradilan pidana yang demikian itu perlu pemahaman lebih lanjut untuk menumbuhkan sikronisasi dari struktur hukum, substansi hukum dan budaya hukum.

Pemahaman tentang sistem peradilan pidana seperti uraian tersebut diatas yang perlu ditonjolkan adalah menumbuhkan upaya sinkronisasi struktur hukum/aparat sebagai subsistem peradilan pidana yang dalam hal ini merupakan "the integrated administration of criminal justice system", baik menunjukkan kerjasama keseluruhan aparat dalam arti psysical system maupun kebersamaan mewujudkan konsep-konsep baru yang tersusun secara teratur dari berbagai solusi masalah dalam arti abstract system. Apabila pokok pikiran yang terakhir ini dapat dipahami, maka instrument sistem lain yang berupa substansi hukum dan budaya hukum secara relative lebih mudah untuk menyesuaikan dengan jaringan sistem peradilan pidana.

Peninjauan kembali bersifat penyempurnaan isi peraturan KUHAP dari kesebalasan masalah itu perlu terobosan dalam menumbuhkan kemanfaatan sistem peradilan pidana beserta dengan doktrin kepustakaan hukumnya. Salah satu terobosan yang telah dilakukan dengan wewenang Surat Edaran/Fatwa Mahkamah Agung dan dalam hal tertentu wewenang Mahkejapol akan bermanfaat daripada menunggu perubahan dengan amandemen/suplemen Undang-Undang baru, kecuali bagi aliran legisme.

Mengenai masalah Gugatan Pihak Ketiga dalam perkara pidana khusus dan masalah penekalan keterlibatan Terdakwa/Tersangka dalam kejahatan internasional atau transnasional, 
memerlukan pertimbangan dasar Hak Asasi Manusia dan konvensi internasional. Kasus gugatan pihak ketiga dalam perkara pidana khusus menjadi bagian dari hukum acara pidana khusus eksepsional tidak dapat dimasukkan dalam aturan hukum acara pidana umum, karena memang mengandung doktrin penyimpangan hukum. Sedangkan dalam hal larangan orang untuk melakukan perjalanan keluar negeri terutama berstatus orang asing juga perlu pertimbangan dari konvensi internasional dan deklarasi Hak Asasi Manusia.

Oleh karena itu, penyelenggaraan panel diskusi antara aparat (the administration of criminal justice system) bersama akademisi, akan dapat membantu pemecahan masalah hukum untuk memperlancar fungsi positif dari hakekat sistem peradilan pidana.

Perkembangan ilmu pengetahuan tumbuh kecenderungan berpikir maju yang antara lain telah membedakan dengan tajam antara institusi peradilan pidana dan institusi peradilan pidana dan institusi pengadilan yang akan memutus perkara pidana.

Prosesperkarapidanaterdapatkecenderungan dapat diputus dan berakhir pada tingkat peradilan pidana hanya sampai tahap penyelesaian di kepolisianataudikejaksaan, apabilaperkembangan penegakan hukumnya telah mengikuti fungsi kontrol negatif bagi perkara tertentu, berdaarkan pertimbangan "utility" untuk pemanfaatan hukum yang efektif, praktis dan rational.

Penegakan hukum dengan control negatif dianggap sebagai jalan keluar dari masalah Pengadilan menyebut "The wedding cake model" yaitu suatu kenyataan diperadilan pidana akan terdapat disparatis yang besar bagi perkara oleh Hakim yang berbeda dan sering tidak konsisten putusanya.(Poernomo, 2010:48)

Keputusan yang mengandung disparatis dan sering tidak konsisten itu akan dapat mengundang sorotan dari ilmu filsafat yang mengamati masalah keadilan relatif, dari ilmu sosial yang mengamati masalah utilitas, dan dari psikologi yang mengamati masalah "behavioural and human relation".

Keputusan Pengadilan untuk setiap perkara pidana (control positif) masih menjadi pendapat umum bahwa "Sentecing is almost universally viewed as the apex of the criminal justice process, the culmination of protrected investigatory, prosecutorial, defense, administrative, and factfinding effort (Konecni and Ebbesen, 1982). Standarprofesi dari putusan Pengadilan seharusnya untuk setiap penerapan hukum dan sanksi hukum yang berdasarkan ilmu pengetahuan hukum yang telah berkembang maju (penal law reform) dari segala perubahan dalam sistem hukum yang terbuka terhadap hasil perkembangan ilmu-ilmu pengetahuan yang relevan.

\section{B. Hakim Komisaris dan Perlindungan Hak Asasi Manusia Terhadap Rekayasa Kasus}

Pembahasan mengenai Hakim Komisaris dalam RUU KUHP dari Kementerian Hukum dan HAM RI dikatakan bahwa, wewenang hakim komisaris versi Rancangan sama dengan praperadilan sekarang, ditambah dengan wewenang memperpanjang penahanan dan pre trial yang memutuskan layak tidaknya suatu perkara diajukan ke pengadilan atas permintaan jaksa. Mengapa tidak dipakai istilah praperadilan, karena peradilan pidana itu dimulai dari penyidikan sampai terpidana keluar dari penjara. Jadi, tidak mungkin ada hakim pra penyidikan. Istilah lain yang dapat dipakai ialah hakim pra sidang (pre trial). Istilah hakim komisaris dipilih oleh Menteri Hukum dan HAM Hamid Awaludin, dengan alasan istilah itu "baik". Walaupun sudah diterangkan bahwa hakim komisaris tidak sama dengan rechter-commisaris di Nederland, tetap ada pihak yang alergi terhadap istilah yang berbau Belanda. Mereka kurang perhatikan, ketentuan dalam KUHAP justru ditiru secara utuh dari KUHAP (strafvordering) Nederland, seperti upaya hukum termasuk peninjauan kembali (herziening) yang 99\% ditiru dari aturan herziening di Nederland, seperti putusan bebas dan lepas dari segala tuntutan hukum tidak boleh diajukan PK, yang sudah beberapa kali dilanggar oleh Mahkamah Agung.

Perbedaan lain antara praperadilan dan hakim komisaris versi KUHAP adalah :

1. Hakim komisaris dilepaskan dari organisasi pengadilan negeri dan berdiri sendiri dan independen di luar struktur pengadilan negeri, walaupun hakimnya direkrut secara ketat dari hakim pengadilan negeri melalui seleksi PANSEL di Pengadilan Tinggi, karena dibutuhkan hakim yang jujur, 


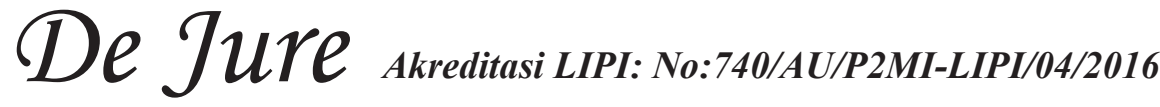

berpengalaman, berani dan mempunyai hati nurani untuk kepentingan nusa dan bangsa.

Alasan: Jika wewenang memperpanjang penahanan yang tersangka harus dibawa secara fisik ke hakim untuk dilakukan penahanan, sesuai dengan ketentuan Pasal 9 dari ICCPR yang telah diratifikasi oleh Pemerintah Indonesia dengan Undang-Undang Nomor 12 Tahun 2005 menyatakan sebagai berikut :

1) Setiap orang berhak atas kebebasan dan keamanan pribadi. Tak seorangpun boleh dikenai penangkapan atau penahanan secara sewenang-wenang. Tak seorangpun boleh dirampas kebebasannya kecuali berdasarkan dan sejalan dengan prosedur yang ditetapkan hukum

2) Setiap orang yang ditangkap harus diberitahu, pada saat penangkapan, mengenai alasan-alasan penangkapan terhadapnya dan harus segera diberitahu mengenai segala tuduhan yang dikenakan padanya.

3) Setiap orang yang ditangkap atau ditahan atas suatu tuduhan kejahatan harus segera dibawa ke muka seorang hakim atau pejabat lain yang dibenarkan oleh hukum untuk menjalankan kewenangan yudisial dan harus berhak untuk diadili dalam kurun waktu yang wajar atau untuk dibebaskan. Menurut aturan umum, tidak diperbolehkan menahan orang-orang yang menunggu untuk diadili, namun pembebasan harus berdasarkan jaminan untuk muncul dalam sidang pengadilan, pada setiap tahap acara yudisial yang lain, dan, bila masanya tiba, pada saat keputusan hakim djijatuhkan.

4) Setiap orang yang dirampas kebebasannya melalui penangkapan atau penahanan harus berhak untuk mengajukanperkarakemukapengadilan, agar pengadilan dapat memutuskan tanpa penundaan waktu mengenai keabsahan penahanan terhadapnya dan perintah pembebasannya apabila penangkapan itu tidak syah.
5) Setiap orang yang telah menjadi korban penangkapan atau penahanan secara sewenang-wenang harus berhak atas kompensasi yang dapat diberlakukan.

International Covenant on Civil and Political Rights yang sudah diratifikasi dan telah diundangkan oleh Indonesia dengan Undangundang Nomor 12 Tahun 2005, dilakukan oleh hakim (praperadilan) di Pengadilan Negeri), maka betapa sibuknya hakim di Pengadilan Negeri menerima dan memeriksa secara fisik tersangka, saksi, yang dihadiri oleh polisi, jaksa dan penasihat hukum setiap hari. Dapat dibayangkan yang sekarang rata-rata 30 orang tahanan baru dimasukkan ke lembaga Salemba oleh Jaksa. Jika perpanjangan penahanan dengan surat saja tanpa dilihat secara fisik tersangka dan tanpa Tanya jawab seperti perpanjangan penahanan sekarang yang dilakukan oleh jaksa tanpa melihat secara fisik dan duduk perkara secara mendetail, memang tidka perlu dibentuk hakim khusus.

Untuk memperpanjang penahanan oleh hakim sesuai dengan Covenant, maka tersangka harus dibawa (secara fisik) segera (promptly) ke hakim untuk dilakukan penahanan. Untuk itu, di Perancis dibentuk hakim khusus yang namanya juge des liberte et de la detention (hakim pembebasan dan penahanan). Hakim ini duduk setiap hari kerja menunggu tersangka dibawa kepadanya oleh polisi dan jaksa. Sebelum menandatangani surat perintah penahanan hakim itu menanyakan beberapa hal mengenai duduk perkara. Ruang hakim ini tidak lebih dari empat meter persegi dengan perabotan ala kadarnya. Penasihat hukum boleh hadir dan memohon dengan alasan agar tersangka tidak ditahan. Lamanya penahanan 400 hari sampai sidang pengadilan hingga ke Mahkamah Agung selesai. Di Nederland yang memperpanjang penahanan tetap rechter-commisaris yang juga tersangka dibawa secara fisik. Perbedaan dengan Prancis, sidang penahanan di Nederland tertutup dengan semua pintu terkunci secara elektronik sedangkan di Prancis terbuka untuk umum. Pemeriksaan sebelum penandatanganan surat perintah penahanan oleh rechter-commisaris bahkan dapat mendengar keterangan saksi termasuk saksi di luar negeri melalui tanya-jawab teleconference (ruangan sidang penahanan di Nederland penuh dengan peralatan elektronik). Lamanya penahanan oleh rechter-commisaris hanya 14 haris yang dapat 
diperpanjang oleh hakim majelis selama 3 kali 30 hari. Penahanan oleh penyidik (polisi) hanya enam jam kecuali perkara serius seperti pembunuhan dan terorisme selama 3 kali 24 jam. Di Prancis penahanan oleh penyidik (polisi) hanya enam jam kecuali perkara serius seperti pembunuhan dan terorisme selama 3 kali 24 jam. Di Prancis penahanan oleh penyidik (polisi) hanya satu kali 24 jam yang dapat diperpanjang jaksa selama satu kali 24 jam sebelum dibawa secara fisik ke hakim pembebasan dan penahanan.

Penahanan yang dilakukan penyidik berdasarkan Rancangan ialah lima kali 24 jam. Jangka waktu paling Iama bagi negara yang menandatangani covenant. Penahanan yang dilakukan oleh polisi Malaysia hanya satu kali 24 jam, yang selanjutnya harus dibawa ke hakim. Di Thailand, ada hakim piket 24 jam selama seminggu untuk menandatangani surat perintah penahanan.

2. Perbedaan wewenang yang lain antara hakim praperadilan dan hakim komisaris versi Rancangan ialah hakim praperadilan hanya menunggu adanya tuntutan dari pihak yang berkepentingan sedangkan hakim komisaris dapat proaktif menentukan suatu penghentian penyidikan misalnya, tidak sah. Saling menuntut ke praperadilan antara penyidik dan penuntut umum ditiadakan, karena dipandang antara penyidik dan penuntut umum merupakan satu pihak berhadapan dengan tersangka / penasihat hukum di pihak lain.

3. Hakim Komisaris juga berwenang memutus suatu perkara layak atau tidak layak diajukan ke pengadilan, suatu hal yang sejak lama diperjuangkan oleh Adnan Buyung Nasution.

4. Kantor Hakim Komisaris di atau dekat Rutan agar tahanan langsung dimasukkan ke tahanan tanpa dibawa lagi pulang.

Menurut Andi Hamzah masalah lain mengapa "penyelidikan tidak ada dalam RUU KUHAP? Memang semula ada "Penyelidikan" dalam Racangan. Namun atas usul dari anggota Tim Dr. Luhut Pangaribuan, maka hal itu ditiadakan. Memang kami belum menemukan KUHAP negara lain yang mengatur "penyelidikan" atau "reserse" atau "intelijen" dalam KUHAP.
Hal ini tidak berarti kepolisian tidak dapat lagi melakukan "penyelidikan". Hal itu diatur dalam undang-undang Kepolisian bukan dalam KUHAP. Penyelidikan itu tidak mesti berdasarkan undangundang menurut asas legalitas. Asas legalitas berlaku pada hukum acara pidana, yaitu "hukum acara pidana dijalankan hanya berdasarkan tata cara yang diatur dengan undang-undang". Intelijen tidak tunduk pada aturan ketat undang-undang. Asal saja tidak melanggar ketentuan undangundang. Kejaksaan pun tetap dapat melakukan kegiatan penyelidikan yang dilakukan oleh JAM Intelijen. Yang tidak mengatur adanya wewenang penyelidikan ialah penyidik pegawai negeri (sipil) jika tidak diatur dalam undang-undang sektoral mereka, kecuali jawatan pajak yang sudah ada bagian intelijen pajak.

\section{Hubungan RUU tentang KUHP dengan RUU} tetang KUHAP

Hukum acara pidana sebagai hukum pidana formil bukanlah hukum yang berdiri melainkan terkait dan bergantung kepada materiil, yakni hukum yang hendak ditegakkan melalui hukum acara pidana. Tidak ada maknanya, jika hukum acara pidananya bagus dan sempurna, tetapi dalam pembentukan normanya tidak mengacu atau mendasarkan kepada norma hukum pidana materiil. Oleh sebab itu, membaca Naskah Akademik RUU tetang HAP pikiran penulis selalu menghubungkan dengan norma hukum pidana materiil dalam KUHP dan hukum pidana materiil dimuat dalam undang-undang di luar KUHP sebagai hukum pidana materiil positif, serta RUU tentang KUHP sebagai hukum pidana materiil yang hendak dibentuk.

\section{Pencari Keadilan dalam hukum pidana}

KUHAP dalam dokumen pembentukannya menegaskan bahwa tersangka-terdakwa-terdakwa sebagai "pencari keadilan", maka tersangkaterdakwa-terpidana memperoleh perhatian dan perlindungan hukum dengan porsi pengaturan hak-haknya yang cukup besar (bahkan ada yang mengatakan 'kecolongan', karena menimbulkan beban yang memberatkan kepada aparat penegak hukum). KUHAP dapat dikatakan sebagai suatu hukum yang substansi pengaturannya berorientasi kepada pelaku. Selama \pm 30 tahun KUHAP hak-hak yang dimiliki oleh pelaku, terutama selama 10 tahun terakhir ini, sedikit demi sedikit dikurangi melalui undang-undang yang mengatur hukum acara pidana tersebar dalam 


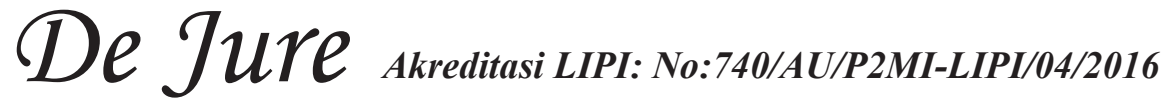

undang-undang di luar KUHAP. Pengurangan tersebut tidak berarti pencabutan terhadap hakhak tersangka-terdakwa-terpidana yang telah ada sebelumnya, melainkan pengurangan kualitas dalam pelaksanaan atau pemenuhan hak-hak hukumnya (atau 'digerogoti') sedemikian rupa yang esensinya bertentangan dengan filsafat yang mendasari pembentukan norma hukum dalam KUHAP atau bertentangan politik hukum dalam rangka pemberian perlindungan hukum terhadap tersangka-terdakwa-terpidana.

\section{Perlindungan terhadap saksi dan korban}

Perlu dibedakan antara saksi dan korban. Sebaiknya pengaturannya dipisahkan secara tegas antara pengertian saksi dan pengertian korban. Pengaturannya juga dalam bab atau bagian yang terpisah, sehingga akan tampak jelas hak-hak hukumnya sebagai saksi dan hak-hak hukumnya sebagai korban, saksi tidak mesti menjadi korban dan korban (hidup) adalah saksi. Dengan memuat dalam bab atau bagian tersendiri akan memudahkan usaha untuk mengimplementasikan kebijakan hukum acara yang berorientasi kepada pelanggar dan korban kejahatan (kebijakan yang seimbang). Mengenai pengaturan korban kejahatan, lihat uraian sebelumnya dalam uraian nomor 2 (pencari keadilan dalam hukum pidana).

4. Hubungan penyidik dan penuntut umum

Persoalan bukan terletakpada hubungan antara penyidik dan penuntut umum, hal yang lebih penting menurut penulis adalah kebijakan penyusunan hukum acara berbasis bertumpu pada tiga tahapan, yaitu tahap pra-adjukasi, ajudikasi, dan tahap pascaajudikasi yang berkaitan dengan dua pilar kekuasaan. Tahap praajudikasi masuk wilayah kompetensi eksekutif, ajudikadi menjadi kompetensi yudikatif, dan pasca-ajudikasi menjadi kompetensi eksekutif. Atas dasar pertimbangan tersebut berkaitan dengan kompetensi kesekutif, sebaiknya tidak perlu ada pemisahan secara tegas kewenangan penyidikan dan penuntutan, karena keduanya dibawah kekuasaan eksekutif. Sebaliknya, perlu ada pemisahan yang tegas antara wilayah kekuasaan eksekutif dan yudikatif, yaitu antara penyidikan dan penuntutan serta pelaksanaan pidana di satu pihak dengan pemeriksaan sidang pengadilan oleh hakim di lain pihak. Hakim sebaiknya dijauhkan dari bayangbayang penuntut umum, meskipun keduanya digaji dengan uang Negara. Hakim yang independen dan professional akan mepengaruhi penuntut umum dan penyidik yang professional, sebaliknya hakim yang tidak professional cenderu'ng menutupi kekurangan atau kelemahan jaksa penuntut umum, akan menghidup suburkan penuntut umum dan penyidik yang tidak profesional.

\section{Pembatasan masa tahanan}

Persoalan penahanan perlu dipertegas mengenai beberapa hal, yaitu kapan dan dalam hal apa penyidik dan penuntut umum boleh menahan, ukuran objektif penggunaan wewenang penahan, dan alat kontrol penggunaan wewenang untuk penahanan agar penggunaan wewenang menahan benar-benar selektif.

Menurut penulis, setiap bentuk perampasan kemerdekaan (penahanan) adalah dilarang, kecuali atas putusan atau persetujuan pengadilan/ hakim. Jadi penyidik dan penuntut umum tidak boleh melakukan penahanan terhadap tersangka atau terdakwa, kecuali berdasarkan putusan atau persetujuan pengadilan/hakim. RUU tentang HAP harus berani mengubah bahwa perampasan hak orang dalambentuk penahanantidak diperbolehkan kecuali atas putusan atau ijin pengadilan/hakim.

\section{Intersepsi}

Intersepsi tidak diperbolehkan, karena dalam era teknologi informasi sekarang ini termasuk bentuk pelanggaran hak dasar manusia. Oleh sebab itu, untuk melindungi hak seseorang, intersepsi hanya boleh dilakukan atas dasar putusan atau ijin/persetujan pengadilan/hakim.

Intersepsi hanya dibolehkan apabila untuk kepentingan pengumpulan alat bukti setelah ada dugaan terjadinya pelanggaran hukum pidana, bukan untuk menelusuri atau mencari-cari (siapa tahu ada) suatu pelanggaran hukum pidana. Prinsip berdasarkan putusan pengadilan atau ijin pengadilan/hakim, jika menghadapi suatu keadaan tertentu dapat dilakukan dengan cara lain, prinsipnya ada dugaan terjadinya perbuatan pidana dan keputusan intersepsi diputus secara objektif oleh tim disertai dokumen putusannya disertai dengan bukti permulaan yang cukup untuk menyangka seseorang). Dokumen putusan tersebut penting dapat diuji jika ada dugaan terjadinya penyalahgunaan wewenang dalam melakukan intersepsi oleh lembaga yang diberi wewenang untuk itu.

\section{Hakim komisaris}

Prinsip hukum yang mendasar bahwa perampasan hak orang tidak boleh dilakukan 


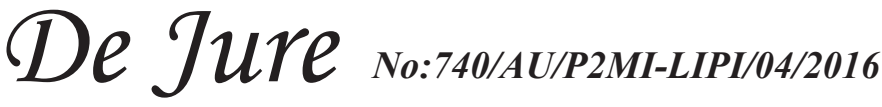

kecuali memiliki wewenang untuk merampas (menahan) dan wewenang tersebut dipergunakan atas putusan pengadilan atau ijin pengadilan/ hakim. Demikian juga penetapan seseorang yang menjadi tersangka juga atas dasar putusan pengadilan atau ijin/persetujuan pengadilanjhakim setelah memeriksa berkas pemeriksaan oleh penyidik.

8. Pembatasan upaya hukum kasasi ke MA

Kasasi adalah bentuk upaya hukum oleh pencari kedadilan untuk mencari keadilan yang belum diperoleh melalui pengadilan sebelumnya, yaitu pengadilan negeri dan pengadilan tinggi. Mahkamah Agung merupakan benteng terakhir bagi pencari keadilan untuk menemukan keadilan dalam penegakan hukum pidana. Pertanyaan yang fundamental adalah apakah upaya hukum bagi pencari keadilan untuk menemukan keadilan harus dibatasi?

Sebaiknya juga diperlukan staf ahli hukum yang professional Mahkamah Agung sebagai alternatif jika tidak menyertujui rekrutimen calon hakim Agung yang bersumber dari non-hakim karier.

\section{KESIMPULAN}

Bahwa kehadiran Hakim Komisaris dalam proses pidana adalah upaya untuk dapat memberikan perlindungan seseorang dari jerat hukum yang selalu berdampak pada hak-hak selaku terdakwa.

Untuk mencegah terjadinya politisasi terhadap substansi hukum dan menjaga keotonoman dari hukum termasuk lembaganya, kewenangan yang terkait dengan pembentukan, pelaksanaan, dan penyelesaian sengketa atau penyimpangan harus dipisahkan secara tegas agar tidak saling mengintervensi oleh yang satu terhadap yang lainnya.

\section{SARAN}

Ketentuan Internasional mengenai hakhak masyarakat Internasional harus dapat diimplementasikan baik dengan melalui ratifikasi, maupun secara diam-diam pemerintah

Perlunya norma hukum yang diatur berdasarkan nilai dasar tertentu 


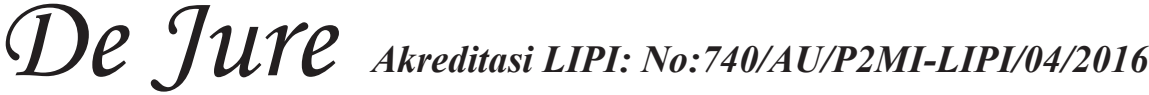

\section{DAFTAR KEPUSTAKAAN}

\section{A. Buku}

Andi Hamzah, Delik-delik di Luar KUHP, Jakarta: Sinar Grafika, 1978.

Andi Hamzah dan Bambang Waluyo. Delikdelik terhadap Penyelenggara Peradilan (Contempt of Court), Cetakan I. Jakarta: Sinar Grafika, 1989.

Ahmad Ubbe, KUHAP dan Kemajuan Teknologi. Jakarta: BPHN.2009

Amrullah M. Arief, Kejahatan Korporasi. Malang: Bayumedia Publishing. 2006 ,Politik Hukum Pidana. Malang: Bayumedia Publishing. 2003

Ancel, Marc, Social Defence, A Modern Approach to Criminal to Criminal Problem. London: Routledge \& Paul Kegan. 1965

Andrea, Fockema, Kamus Istilah Hukum: Belanda - Indonesia. Bandung: Bina Cipta. 1983

Anwar, Yesmil dan Adang, Pemburuan Hukum Pidana: Reformasi Hukum Pidana. Jakarta: Grasindo. 2008

Assidiqie, Jimly, Format Kelembagaan Negara dan Pergeseran Kekuasaan Dalam UUD 1945. Yogyakarta: FH-UII Press. 2004 Pembaruan Hukum Pidana Indonesia. Bandung: Angkasa. 1995

Arief Barda Nawawi, Masalah Pemidanaan Sehubungan Dengan Perkembangan Kriminalitas dan Perkembangan Delik-delik Khusus Dalam Masyarakat Modern. Jakarta: BPHN Departemen Kehakiman. 1980 , Masalah-masalah Hukum, Nomor 16. Semarang: FH UNDIP. 1974 , Bunga Rampai, Kebijakan Hukum Pidana. Bandung: PT. Citra Aditya Bhakti. 2002

,Kapita Selekta Hukum Pidana. Bandung: PT. Citra Aditya Bhakti. 2003

Indrayanto SenoAdji. Praperadilan ataukah Hakim Komisaris: Ide ke Arah Perluasan Wewenang. Makalah disampaikan dalam Sosialisasi RUU KUHAP yang diselenggarakan oleh Ditjen Peraturan Perundang-undangan Departemen
Kehakiman dan HAM di Jakarta 22 Juli 2002.

KG Widjaja. Asas Praduga Tak Bersalah dan Perspektif Pembangunan Teori-teori Hukum (Pidana) di Indonesia. Makalah pada Seminar Program Pascasarjana UI tanggal 17 Januari 1995.

Loebby Loqman. Praperadilan di Indonesia. Jakarta: Ghalia Indonesia, 1990., hal. 54. Diambil dari Gregory Churchill. Habeas Corpus: Peranan Upaya Habeas Corpus Dalam Pengawasan Pelaksanaan Hukum Acara Pidana di Amerika Serikat. Seminar Praperadilan, PERADIN. Jakarta, 1982.

Luhut MP Pangaribuan. Advokat dan Contempot of Court: Suatu Proses di Depan Dewa Kehormatan Profesi. Cetakan I. Jakarta: Djambatan, 1996.

Mardjono Reksodiputro (a) Kriminologi dan Sistem Peradilan Pidana Buku II. Cetakan I. Jakarta: Pusat Pelayanan dan Keadilan dan Pengabdian Hukum (d/h Lembaga Kriminologi) UI, 1994.

\section{Hak Asasi Manusia dalam}

Sistem Peradilan Pidana Buku I Cetakan I. Jakarta: Pusat Pelayanan dan Keadilan dan Pengabdian Hukum (d/h Lembaga Kriminologi) UI, 1994.

Muladi, Kapita Selekta Sistem Peradilan Pidana, Semarang: Badan Penerbit universitas Diponegoro, 2002.

M. Yahya Harahap, Pembahasan Permasalahn dan Penerapan KUHAP Pemeriksaan Sidang Pengadilan, Banding, Kasasi, dan Peninjauan Kembali. Jakarta: sinar Grafika, 2001.

Neil C. Chamelin, et.al. Introduction to Criminal Justice, New Jersey: Prentice-Hall, 1975.

UNAFEI. Criminal Justice System: The Quest for an Integrated Approach. UNIAFEI, 1982.

Oemar Senoadji. Peradilan Bebas Negara Hukum. Jakarta: Erlangga, 1980.

O.C. Kaligis, Tugas dan Fungsi Jaksa Dalam Melakukan Penyidikan Perkara Pidana, Bandung: Alumni, 2001. 


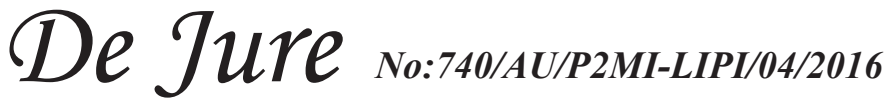

\section{B. Peraturan Perundang-undangan}

Indonesia, Undang-Undang Nomor 1 Tahun 1946 tentang Peraturan Hukum Pidana , Undang-Undang Nomor 8 Tahun 1981 tentang Hukum Acara Pidana

, Undang-Undang Nomor 2 Tahun 2002 tentang Kepolisian Republik Indonesia

,Undang-Undang Nomor 16 Tahun 2004 tentang Kejaksaan Republik Indonesia

,Undang-Undang Nomor 3 Tahun 2009 tentang Mahkamah Agung

,Undang-Undang Nomor 48 Tahun 2009 tentang Kekuasaan Kehakiman 